\title{
Hepatoma Research: the beginning of a new forum
}

\author{
Joseph F. Buell \\ Tulane Transplant Institute, Tulane University, New Orleans, LA 70118, USA
}

Address for correspondence:

Prof. Joseph F. Buell, Tulane Transplant Institute, Tulane University, New Orleans, LA 70118, USA.

E-mail: jbuell1@tulane.edu

Received: 06-02-2015, Accepted: 19-02-2015

\section{INTRODUCTION}

Liver cancer, primary hepatocellular carcinoma (HCC) or hepatoma has become the third leading cause of death from cancer worldwide. ${ }^{[1,2]}$ In 2008, the GLOBOCAN reported 746,300 new cases of HCC diagnosed worldwide with 695,900 HCC-related deaths and a 1.07 incidence to mortality ratio making it the third most fatal cancer world-wide with the vast majority (84\%) of cases concentrated in the developing countries in Asia and Africa. ${ }^{[2,3]}$ HCC is a disparate cancer preferentially afflicting the middle to lower socio-economic segment of the world. ${ }^{[4]}$ The economic cost of HCC is staggering with global expense estimated at $\$ 895.2$ billion a year only followed by cardiac ( $\$ 753.2$ billion) and cerebrovascular disease ( $\$ 298.2$ billion).

Hepatoma Research (Hepatoma Res, ISSN 2394-5079, http://www.hrjournal.net/), this new open access online journal, has been created to improve and promote the international exchange of clinical and academic information about HCC. We invite our peers, clinical and research collaborators alike to contribute to this new journal to improve the international exchange of information in real time to meet this global challenge. Our journal will address all aspect of HCC, including cell biology, pathophysiology, genetics, immunology, pharmacology, medical management as well as radiological and surgical interventions.

\begin{tabular}{|l|c|}
\hline \multicolumn{2}{|c|}{ Access this article online } \\
\hline \multirow{2}{*}{ Website: } & Quick Response Code \\
\hline http://www.hrjournal.net/ & \\
DOI: & \\
10.4103/2394-5079.153290 & \\
&
\end{tabular}

\section{ETIOLOGY}

Currently, HCC predominately (78\%) arises from two chronic liver infections: hepatitis B virus (HBV) and hepatitis C virus (HCV). HBV represents the etiologic factor in $50 \%$ of world-wide HCC cases and was recognized in 1994 by the WHO/IARC with a relative risk ranging from 5 to $98 .^{[5,6]}$ Inactive HBV is also an established risk for HCC with a hazard ratio of 4.6. HBV in Asia, especially in China and Korea, has shown a steady decline through HBV immunization programs. Alternatively, the United States and Japan witnessed a rise in HCV acquired from intravenous drug abuse in the 60's and 80's, which was associated with 80-90\% of HCC cases in Japan and 40-60\% of cases in Italy and the United States with an odds ratio of 1.3-134..$^{[-9]}$ After decades of frustration treating $\mathrm{HCV}$ introduction of new protease inhibitors are achieving $80-100 \%$ viral eradication, which is associated with a decreased the relative risk for the development of HCC. ${ }^{[10-12]}$ Unfortunately complete virologic response does not eradicate the risk of HCC in established HCV-related cirrhosis.

Unfortunately, the progress in viral hepatitis has not addressed the looming cloud of obesity, nonalcoholic fibrotic liver disease (NAFLD) and nonalcoholic steatohepatitis (NASH) on our horizon. In a world of advancing technology, the standard of living including food stores has dramatically increased and subsequently the mean body mass index and incidence of obesity. NAFLD/NASH as an etiologic factor results in excess fatty acids, and hepatocellular steatosis, which elicits fatty acid oxidation and reactive oxidative stress thought to produce epigenetic changes. ${ }^{[13,14]}$

\section{CARCINOGENESIS}

No matter what the agent viral hepatitis, fatty liver or diabetes the principle risk factor in $\mathrm{HCC}$ is the presence of a pre-neoplastic liver. ${ }^{[15,16]}$ In HBV-related HCC, the presence of serum HBV 
DNA has been shown to be a predictor of HCC development synergistic with inflammation. ${ }^{[17]}$ Viral DNA replication and hepatitis B core antigen expression are halted in HBV HCC, while $20 \%$ of cells persist production of hepatitis B surface antigen triggering an immune responses and the secretion of cytokines tumor necrosis factor- $\alpha$, interferon and interleukin-2, which can down regulate the accumulation of HBV RNAs. ${ }^{[18-20]}$

Development of HCV-related HCC is a multistep process including the up regulation of inflammatory cytokines and induction of oxidative stress from chronic hepatitis, fibrosis, liver regeneration, and cirrhosis. ${ }^{[21]}$ The intermediate step is represented by dysplastic nodules with the coexistence of epigenetic and genetic changes that develop into HCC. Multiple pro-inflammatory states appear to be synergistic with HCV including: alcohol, HBV and HIV co-infection, diabetes mellitus, older age, African American race, thrombocytopenia, and smoking. ${ }^{[21-24]}$

Nonalcoholic fibrotic liver disease and NASH is an entity previously classified with cryptogenic cirrhosis with a high relative risk for HCC. Pro-inflammatory states from fatty acids release cytokines, pro-oncogenic signals and stimulate epigenetic changes even in the absence of cirrhosis. ${ }^{[18]}$ Subsequently obese type II diabetics are at twice the risk to develop HCC. ${ }^{[25-27]}$ Alternatively, African Americans are at a lower relative risk for HCC compared to Caucasians based on fat distribution and metabolism. The estimated yearly incidence of HCC development in NASH-cirrhosis (2.6\%) is similar to HCV-cirrhosis (4\%). ${ }^{[28]}$

Genes involved in hepatocarcinogenesis include p53, PIKCA, and $\beta$-catenin. In addition, there are two signaling pathways for cellular differentiation that are frequently disrupted: (1) Wnt- $\beta$-catenin and (2) Hedgehog. WNT signaling appears to be associated with a higher incidence of transformation and pre-neoplastic adenomas. ${ }^{[29]}$

\section{SURVEILLANCE}

The American Association for the Study of Liver Diseases advocates bi-annual ultrasound surveillance for high-risk patients. ${ }^{[30]}$ Cost-effectiveness is meet with two criteria: (1) annual incidence $>1.5 \%$ per year and (2) threshold of $\$ 50,000$ per quality-adjusted life year (QALY). Several economic analyzes confirm Child-Pugh Class A patients increase life expectancy with cost effectiveness of $\$ 26,000$ and $\$ 55,000$ per QALY. The best data on surveillance comes from a prospective Chinese trial. ${ }^{[31-35]}$ Surveillance is recommended for all cirrhotics, HBV carriers if they are Africans older than age 20 years, Asians older than 40 years or have a family history of HCC. However, debate on the utility of AFP continues.
Unfortunately ultrasound is highly operator dependent with a variable sensitivity of $30-70 \%$, and most importantly $<20 \%$ of patients compliant with biannual exams. ${ }^{[36-38]}$

\section{DIAGNOSIS}

Hepatocellular carcinoma is diagnosed by contrast-enhanced computerized tomography (CT) or magnetic resonance imaging (MRI). Early arterial phase enhancement is seen in the tumor followed by venous phase dropout. These characteristics carry result in $90 \%$ sensitivity and $95 \%$ specificity for lesions greater than one centimeter. ${ }^{[39]}$ In 2013, the American College of Radiology introduced the Liver Imaging Reporting and Data System to standardize the reporting and data collection of CT and MRI for HCC. ${ }^{[40]}$ In efforts to improve lower cost technology, contrast-enhanced ultrasound was introduced with a $90 \%$ sensitivity, $99 \%$ specificity and $89 \%$ diagnostic accuracy. ${ }^{[1]}$ The diagnostic accuracy of MRI has been improved by dual contrast agents like Eovist ${ }^{\circledR}$, which is a hepatobiliary excretion and vascularization markers used to diagnosis HCC. ${ }^{[42]}$ Despite these advances in technology, diagnostics are still encumbered by operator variability and inadequate diagnostic resolution in tumors under $2 \mathrm{~cm}$. The deficiencies in diagnostic screening and sensitivity are seen by the mean tumor size of HCC with the state of Louisiana being $6.5 \mathrm{~cm}$ well above Milan Criteria.

\section{STAGING AND PROGNOSIS}

Multiple staging systems exist for HCC, but the Barcelona Clinic Liver Cancer (BCLC) staging, and prognostic system appear to be the most widely accepted. BCLC incorporates tumor stage, cirrhosis stage, and functional performance status and links stage with a treatment algorithm. ${ }^{\text {[3-45] }}$ Despite multiple valid staging systems, the most attractive system would be the staging of HCC on genomic finger printing directing therapy and resource allocation such as liver transplants.

Very early stage HCC (Stage 0 ) are tumors $<2 \mathrm{~cm}$ have the best prognosis but are hard to identify on imaging. Early stage HCC (Stage A) is solitary lesions or up to three lesions $<3 \mathrm{~cm}$ with preserved liver function (Child-Pugh Class A or B) and reasonable functional status (PS 0-2) with. Their 5-year survivals reach $50-75 \%$. Intermediate stage HCC (Stage B) is multi-nodular with preserved liver function (Child-Pugh Class A or B) and good functional status (PS 0), and no cancer-related symptoms or evidence of vascular invasion. Advanced stage HCC (Stage C) demonstrates vascular invasion or extra-hepatic spread with compromise of functional status (PS 1 or 2) due to HCC. Terminal stage HCC (Stage D) 
have tumor marked with vascular invasion and extra-hepatic spread with decompensated cirrhosis (Child-Pugh Class C), poor functional status (PS $>2$ ).

\section{TREATMENT OPTIONS}

Surgical resection is an excellent option but has a limited utility due to advanced cirrhosis and is employed in $<5 \%$ of patients. ${ }^{[46]}$ Candidates for resection include: (1) Child-Pugh Class A; (2) hepatic venous pressure gradient $<10 \mathrm{mmHg}$; (3) platelet count $>100,000$; (4) future remnant $>25 \%$ (non-cirrhotic); and (5) 50\% (cirrhotic) resulting in a $70 \%$ 5-year survival. ${ }^{[47,48]}$ The future remnant can be augmented by pre-operative portal vein embolization. Unfortunately, the majority of patients develop either new HCC or recurrent tumor within 5-year exceeding 70\% but if the tumor burden remains within Milan they are candidates for salvage transplant. ${ }^{[49,50]}$

Liver transplantation is reserved for unresectable or decompensated cirrhotics with HCC within the Milan criteria: (1) One lesion $\leq 5 \mathrm{~cm}$ and (2) three lesions $\leq 3 \mathrm{~cm}$ could provide a $>70 \% 5$-year survival. ${ }^{[51]}$ Current organ allocation in the United States is performed utilizing Model for End-stage Liver Disease with HCC receiving exception point varying from 22 to 34 points while patients that exceeding Milan are required to be downstaged by pre-transplant locoregional to reduce dropout and potentially post-operative recurrence. ${ }^{[52,53]}$ European centers take an alternative approach whereby laparoscopic resection is liberally employed, and those patients with the highest risk for recurrence are sent for the liver transplant. These factors include lymphovascular invasion and nonencapsulated tumors.

Locoregional therapies include: (1) percutaneous ethanol injection; (2) cryotherapy; (3) radiofrequency ablation; (4) microwave therapy; (5) irreversible electroporation (IEP); and (6) yttrium. Percutaneous ethanol is the least expensive and frequently performed in the office with ultrasound. Thermal ablation is more complex but very effective in smaller tumors (2-3 cm): 70-80\% and intermediate tumors (3-5 cm): 50\%. Radiofrequency ablation, microwave ablation, and IEP all result in thermal injury, tissue necrosis and apoptosis propagation. ${ }^{[54,55]}$

Several drug delivery systems have been introduced including ThermoDox $^{\circledR}$ and Delcath ${ }^{\circledR}$ a percutaneous intrahepatic, hepatic perfusion device. ThermoDox ${ }^{\circledR}$ is a liposomal delivery system for doxorubicin triggered by heat delivered by an ablation device. ${ }^{[56]}$ The Delcath ${ }^{\circledR}$ device delivers high doses of chemotherapy to the liver in an isolated circuit under hyperthermic conditions.

Radioembolization or Y-90 is the radiation delivered through microembolization beads. Two versions of Y-90 exist, smaller beads for end capillary embolization and the larger for arterial embolization both designed to deliver up to $150 \mathrm{~Gy}$ of beta radiation. ${ }^{[57]}$ Both have relative complications related to their size, embolization stasis methods and radiation intensity. Elevated bilirubin and portal vein thrombosis have become relative contraindications using selective and super-selective approaches. Y-90 has a median survival of 17.2 months in Child-Pugh A cirrhotics and 7.7 months in Child-Pugh B cirrhotics. ${ }^{[58]}$

Trans-arterial chemoembolization (TACE) is a widely adopted therapy for HCC embolizing tumor's arterial supply with or without doxorubicin. TACE has a survival advantage at 1 year $(82 \%$ vs. $63 \%)$ and 2 years (63\% vs. $27 \%$ ) compared to controls. ${ }^{[59,60]}$ Increased bilirubin ( $>2.5 \mathrm{mg} / \mathrm{dL}$ ) and portal vein thrombosis are no longer an absolute contraindications utilizing a selective or super-selective approach to tumors. ${ }^{[61]}$ Drug-eluting beads have been developed to provide stable and prolonged delivery to decrease doxorubicin toxicity resulting in higher rates of complete response. ${ }^{[62,63]}$ Chemoembolization results in the tumor ischemia and hypoxia, which stimulate angiogenic growth factors including vascular endothelial growth factor (VEGF), which potentially-induce tumor angiogenesis and tumor recurrence. ${ }^{[64]}$

Sorafenib is a tyrosine kinase inhibitor that was shown to have a survival benefit over best supportive care in two pivotal studies: (1) sorafenib in patients with advanced HCC and Asian Pacific trials in patients with Child-Pugh Class A cirrhosis, and (2) advanced HCC compatible with Stage C. ${ }^{[65,66]}$ Sorafenib is currently the primary chemotherapeutic agent for the treatment of unresectable or recurrent HCC. Multiple adjuvant trials are under way to evaluate the synergistic effects of sorafenib post-resection and ablative therapies. Brivanib is an oral selective dual inhibitor of the fibroblast growth factor and the VEGF pathway, which is being evaluated as a second-line therapy for the management of VEGF stimulation. ${ }^{[67]}$ Other agents under investigation include: erlotinib, bevacizumab, lapatinib, gefitinib and cetuximab.

\section{CONCLUSION}

Hepatocellular carcinoma is the third leading cause of cancer mortality world-wide preferentially afflicting lower socioeconomic patients. Dramatic advances have been made to reduce the incidence of HBV and HCV including HBV immunization strategies and the introduction of new direct acting antiviral drugs for the treatment of HCV. With eradication strategies for HBV and HCC, NAFLD and NASH will become the principle etiology for HCC. HCC will become a disease of the obese.

Obesity itself will complicate HCC management particularly surgical interventions including resection and liver transplantation. Concentrated efforts should be placed on early diagnosis. Early diagnosis not only improves patient survival and is far more cost 
effective than any late intervention. Several diagnostic strategies lie in the future with the potential identification of circulating tumor cells or identification of a premalignant signature like epigenetic changes. Despite our best efforts to diagnose HCC in earlier stages, this will not be feasible in most. Therapeutic efforts should be redoubled into the development of new drug delivery systems and platforms to improve chemotherapeutic monotherapy or platform assisted surgery with agents such as nanoparticle and liposomal delivery systems.

\section{REFERENCES}

1. Surveillance Research Program, National Cancer Institute Fast Stats: an interactive tool for access to SEER cancer statistics; November 10, 2011. Available from: http://www.seer.cancer.gov/ faststats. [Last accessed on $2015 \mathrm{Feb} 04$ ].

2. Ferlay J, Shin HR, Bray F, Forman D, Mathers C, Parkin DM. Estimates of worldwide burden of cancer in 2008: GLOBOCAN 2008. Int J Cancer 2010;127:2893-917.

3. Pourhoseingholi MA, Vahedi M, Baghestani AR. Burden of gastrointestinal cancer in Asia: an overview. Gastroenterol Hepatol Bed Bench 2015;8:19-27.

4. Liver Cancer. Available from: http://www.livestrong.com. [Last accessed on 2015 Feb 04].

5. Amin J, Dore GJ, O’Connell DL, Bartlett M, Tracey E, Kaldor JM, Law MG. Cancer incidence in people with hepatitis B or C infection: a large community-based linkage study. J Hepatol 2006;45:197-203.

6. Ulcickas Yood M, Quesenberry CP Jr, Guo D, Wells K, Shan J, Sanders L, Skovron ML, Iloeje U, Caldwell C, Manos MM. Incidence of hepatocellular carcinoma among individuals with hepatitis B virus infection identified using an automated data algorithm. J Viral Hepat 2008;15:28-36

7. World Health Organization. International Agency for Research on Cancer. IARC Monographs on the Evaluation of Carcinogenic Risks to Humans. Hepatitis Viruses. Vol. 59. Lyon, France: International Agency for Research on Cancer; 1994.

8. Nguyen VT, Law MG, Dore GJ. Hepatitis B-related hepatocellular carcinoma: epidemiological characteristics and disease burden. $J$ Viral Hepat 2009; 16:453-63.

9. But DY, Lai CL, Yuen MF. Natural history of hepatitis-related hepatocellular carcinoma. World J Gastroenterol 2008;14:1652-6.

10. Bruno S, Stroffolini T, Colombo M, Bollani S, Benvegnù L, Mazzella G, Ascione A, Santantonio T, Piccinino F, Andreone P, Mangia A, Gaeta GB, Persico M, Fagiuoli S, Almasio PL; Italian Association of the Study of the Liver Disease (AISF). Sustained virological response to interferon-alpha is associated with improved outcome in HCV-related cirrhosis: a retrospective study. Hepatology 2007;45:579-87.

11. Lok AS, Everhart JE, Wright EC, Di Bisceglie AM, Kim HY, Sterling RK, Everson GT, Lindsay KL, Lee WM, Bonkovsky HL, Dienstag JL, Ghany MG, Morishima C, Morgan TR; HALT-C Trial Group. Maintenance peginterferon therapy and other factors associated with hepatocellular carcinoma in patients with advanced hepatitis C. Gastroenterology 2011;140:840-9.

12. Kwon H, Lok AS. Does antiviral therapy prevent hepatocellular carcinoma? Antivir Ther 2011;16:787-95.

13. Bugianesi E, Leone N, Vanni E, Marchesini G, Brunello F, Carucci P, Musso A, De Paolis P, Capussotti L, Salizzoni M, Rizzetto M. Expanding the natural history of nonalcoholic steatohepatitis: from cryptogenic cirrhosis to hepatocellular carcinoma. Gastroenterology 2002;123:134-40.

14. Stickel F, Hellerbrand C. Non-alcoholic fatty liver disease as a risk factor for hepatocellular carcinoma: mechanisms and implications. Gut 2010;59:1303-7.

15. Tsukuma H, Hiyama T, Tanaka S, Nakao M, Yabuuchi T, Kitamura T,
Nakanishi K, Fujimoto I, Inoue A, Yamazaki H, Kawashima T. Risk factors for hepatocellular carcinoma among patients with chronic liver disease. N Engl J Med 1993;328:1797-801.

16. El-Serag HB, Davila JA, Petersen NJ, McGlynn KA. The continuing increase in the incidence of hepatocellular carcinoma in the United States: an update. Ann Intern Med 2003;139:817-23.

17. Liu CJ, Chen BF, Chen PJ, Lai MY, Huang WL, Kao JH, Chen DS. Role of hepatitis B virus precore/core promoter mutations and serum viral load on noncirrhotic hepatocellular carcinoma: a case-control study. J Infect Dis 2006;194:594-9.

18. Yang HI, Yeh SH, Chen PJ, Iloeje UH, Jen CL, Su J, Wang LY, Lu SN, You SL, Chen DS, Liaw YF, Chen CJ; REVEAL-HBV Study Group. Associations between hepatitis B virus genotype and mutants and the risk of hepatocellular carcinoma. J Natl Cancer Inst 2008;100:1134-43.

19. Iannacone M, Sitia G, Ruggeri ZM, Guidotti LG. HBV pathogenesis in animal models: recent advances on the role of platelets. $J$ Hepatol 2007;46:719-26.

20. ReidAE, Koziel MJ,Aiza I, Jeffers L, Reddy R, SchiffE, Lau JY, Dienstag JL, Liang TJ. Hepatitis C virus genotypes and viremia and hepatocellular carcinoma in the United States. Am J Gastroenterol 1999;94:1619-26.

21. Liang TJ, Heller T. Pathogenesis of hepatitis C-associated hepatocellular carcinoma. Gastroenterology 2004;127:S62-71.

22. Hassan MM, Hwang LY, Hatten CJ, Swaim M, Li D, Abbruzzese JL, Beasley P, Patt YZ. Risk factors for hepatocellular carcinoma: synergism of alcohol with viral hepatitis and diabetes mellitus. Hepatology 2002;36:1206-13.

23. Davis GL, Alter MJ, El-Serag H, Poynard T, Jennings LW. Aging of hepatitis $\mathrm{C}$ virus (HCV)-infected persons in the United States: a multiple cohort model of $\mathrm{HCV}$ prevalence and disease progression. Gastroenterology 2010;138:513-21, 521.e1-6.

24. Lok AS, Seeff LB, Morgan TR, di Bisceglie AM, Sterling RK, Curto TM, Everson GT, Lindsay KL, Lee WM, Bonkovsky HL, Dienstag JL, Ghany MG, Morishima C, Goodman ZD; HALT-C Trial Group. Incidence of hepatocellular carcinoma and associated risk factors in hepatitis C-related advanced liver disease. Gastroenterology 2009;136:138-48

25. Yang HI, Sherman M, Su J, Chen PJ, Liaw YF, Iloeje UH, Chen CJ. Nomograms for risk of hepatocellular carcinoma in patients with chronic hepatitis B virus infection. J Clin Oncol 2010;28:2437-44.

26. Kiyosawa K, Umemura T, Ichijo T, Matsumoto A, Yoshizawa $\mathrm{K}$, Gad A, Tanaka E. Hepatocellular carcinoma: recent trends in Japan. Gastroenterology 2004;127:S17-26.

27. El-Serag HB. Hepatocellular carcinoma: recent trends in the United States. Gastroenterology 2004;127:S27-34.

28. Ascha MS, Hanouneh IA, Lopez R, Tamimi TA, Feldstein AF, Zein NN. The incidence and risk factors of hepatocellular carcinoma in patients with nonalcoholic steatohepatitis. Hepatology 2010;51:1972-8.

29. Li P, Cao Y, Li Y, Zhou L, Liu X, Geng M. Expression of Wnt-5a and ß-catenin in primary hepatocellular carcinoma. Int J Clin Exp Pathol 2014;7:3190-5.

30. Bruix J, Sherman M; Practice Guidelines Committee, American Association for the Study of Liver Diseases. Management of hepatocellular carcinoma. Hepatology 2005;42:1208-36.

31. Donato F, Boffetta P, Puoti M. A meta-analysis of epidemiological studies on the combined effect of hepatitis B and C virus infections in causing hepatocellular carcinoma. Int J Cancer 1998;75:347-54.

32. Donato F, Tagger A, Gelatti U, Parrinello G, Boffetta P, Albertini A, Decarli A, Trevisi P, Ribero ML, Martelli C, Porru S, Nardi G. Alcohol and hepatocellular carcinoma: the effect of lifetime intake and hepatitis virus infections in men and women. Am J Epidemiol 2002;155:323-31.

33. Zhang BH, Yang BH, Tang ZY. Randomized controlled trial of screening for hepatocellular carcinoma. J Cancer Res Clin Oncol 2004;130:417-22.

34. Trevisani F, De Notariis S, Rapaccini G, Farinati F, Benvegnù L, Zoli M, Grazi GL, Del PP, Di N, Bernardi M; Italian Liver Cancer Group. Semiannual and annual surveillance of cirrhotic patients for hepatocellular carcinoma: effects on cancer stage and patient 
survival (Italian experience). Am J Gastroenterol 2002;97:734-44.

35. Bolondi L, Sofia S, Siringo S, Gaiani S, Casali A, Zironi G, Piscaglia F, Gramantieri L, Zanetti M, Sherman M. Surveillance programme of cirrhotic patients for early diagnosis and treatment of hepatocellular carcinoma: a cost effectiveness analysis. Gut 2001;48:251-9.

36. Outwater EK. Imaging of the liver for hepatocellular cancer. Cancer Control 2010;17:72-82.

37. Colli A, Fraquelli M, Casazza G, Massironi S, Colucci A, Conte D, Duca P. Accuracy of ultrasonography, spiral CT, magnetic resonance, and alpha-fetoprotein in diagnosing hepatocellular carcinoma: a systematic review. Am J Gastroenterol 2006;101:513-23.

38. Davila JA, Morgan RO, Richardson PA, Du XL, McGlynn KA, El-Serag HB. Use of surveillance for hepatocellular carcinoma among patients with cirrhosis in the United States. Hepatology 2010;52:132-41.

39. Marrero JA, Hussain HK, Nghiem HV, Umar R, Fontana RJ, Lok AS. Improving the prediction of hepatocellular carcinoma in cirrhotic patients with an arterially-enhancing liver mass. Liver Transpl 2005;11:281-9.

40. Mitchell DG, Bruix J, Sherman M, Sirlin CB. LI-RADS (Liver Imaging Reporting and Data System): Summary, discussion, and consensus of the LI-RADS Management Working Group and future directions. Hepatology 2015;61:1056-65.

41. von Herbay A, Westendorff J, Gregor M. Contrast-enhanced ultrasound with SonoVue: differentiation between benign and malignant focal liver lesions in 317 patients. J Clin Ultrasound 2010;38:1-9.

42. Kim JI, Lee JM, Choi JY, Kim YK, Kim SH, Lee JY, Han JK, Choi BI. The value of gadobenate dimeglumine-enhanced delayed phase MR imaging for characterization of hepatocellular nodules in the cirrhotic liver. Invest Radiol 2008;43:202-10.

43. Llovet JM, Brú C, Bruix J. Prognosis of hepatocellular carcinoma: the BCLC staging classification. Semin Liver Dis 1999;19:329-38.

44. Grieco A, Pompili M, Caminiti G, Miele L, Covino M, Alfei B, Rapaccini GL, Gasbarrini G. Prognostic factors for survival in patients with early-intermediate hepatocellular carcinoma undergoing non-surgical therapy: comparison of Okuda, CLIP, and BCLC staging systems in a single Italian centre. Gut 2005;54:411-8.

45. Marrero JA, Fontana RJ, Barrat A, Askari F, Conjeevaram HS, Su GL, Lok AS. Prognosis of hepatocellular carcinoma: comparison of 7 staging systems in an American cohort. Hepatology 2005;41:707-16.

46. Llovet JM, Fuster J, Bruix J. Intention-to-treat analysis of surgical treatment for early hepatocellular carcinoma: resection versus transplantation. Hepatology 1999;30:1434-40.

47. Forner A, Bruix J. East meets the West - portal pressure predicts outcome of surgical resection for hepatocellular carcinoma. Nat Clin Pract Gastroenterol Hepatol 2009;6:14-5.

48. Breitenstein S, Apestegui C, Petrowsky H, Clavien PA. "State of the art" in liver resection and living donor liver transplantation: a worldwide survey of 100 liver centers. World J Surg 2009;33:797-803.

49. Tung-Ping Poon R, Fan ST, Wong J. Risk factors, prevention, and management of postoperative recurrence after resection of hepatocellular carcinoma. Ann Surg 2000;232:10-24.

50. Poon RT. Prevention of recurrence after resection of hepatocellular carcinoma: a daunting challenge. Hepatology 2011;54:757-9.

51. Mazzaferro V, Regalia E, Doci R, Andreola S, Pulvirenti A, Bozzetti F, Montalto F, Ammatuna M, Morabito A, Gennari L. Liver transplantation for the treatment of small hepatocellular carcinomas in patients with cirrhosis. N Engl J Med 1996;334:693-9.

52. Freeman RB, Wiesner RH, Edwards E, Harper A, Merion R, Wolfe R; United Network for Organ Sharing. Results of the first year of the new liver allocation plan. Liver Transpl 2004;10:7-15.

53. Graziadei IW, Sandmueller H, Waldenberger P, Koenigsrainer A, Nachbaur K, Jaschke W, Margreiter R, Vogel W. Chemoembolization followed by liver transplantation for hepatocellular carcinoma impedes tumor progression while on the waiting list and leads to excellent outcome. Liver Transpl 2003;9:557-63.

54. Vilana R, Bruix J, Bru C, Ayuso C, Solé M, Rodés J. Tumor size determines the efficacy of percutaneous ethanol injection for the treatment of small hepatocellular carcinoma. Hepatology 1992;16:353-7.

55. Lencioni R, Crocetti L. A critical appraisal of the literature on local ablative therapies for hepatocellular carcinoma. Clin Liver Dis 2005;9:301-14, viii.

56. May JP, Li SD. Hyperthermia-induced drug targeting. Expert Opin Drug Deliv 2013;10:511-27.

57. Kulik LM, Atassi B, van Holsbeeck L, Souman T, Lewandowski RJ, Mulcahy MF, Hunter RD, Nemcek AA Jr, Abecassis MM, Haines KG 3rd, Salem R. Yttrium-90 microspheres (TheraSphere) treatment of unresectable hepatocellular carcinoma: downstaging to resection, RFA and bridge to transplantation. J Surg Oncol 2006;94:572-86.

58. Sangro B, Carpanese L, Cianni R, Golfieri R, Gasparini D, Ezziddin S, Paprottka PM, Fiore F, Van Buskirk M, Bilbao JI, Ettorre GM, Salvatori R, Giampalma E, Geatti O, Wilhelm K, Hoffmann RT, Izzo F, Iñarrairaegui $\mathrm{M}$, Maini CL, Urigo C, Cappelli A, Vit A, Ahmadzadehfar H, Jakobs TF, Lastoria S; European Network on Radioembolization with Yttrium-90 Resin Microspheres (ENRY). Survival after yttrium-90 resin microsphere radioembolization of hepatocellular carcinoma across Barcelona clinic liver cancer stages: a European evaluation. Hepatology 2011;54:868-78.

59. Llovet JM, Real MI, Montaña X, Planas R, Coll S, Aponte J, Ayuso C, Sala M, Muchart J, Solà R, Rodés J, Bruix J; Barcelona Liver Cancer Group. Arterial embolisation or chemoembolisation versus symptomatic treatment in patients with unresectable hepatocellular carcinoma: a randomised controlled trial. Lancet 2002;359:1734-9.

60. Llovet JM, Bruix J. Systematic review of randomized trials for unresectable hepatocellular carcinoma: chemoembolization improves survival. Hepatology 2003;37:429-42.

61. Georgiades CS, Hong K, D’Angelo M, Geschwind JF. Safety and efficacy of transarterial chemoembolization in patients with unresectable hepatocellular carcinoma and portal vein thrombosis. J Vasc Interv Radiol 2005; 16:1653-9.

62. Varela M, Real MI, Burrel M, Forner A, Sala M, Brunet M, Ayuso C, Castells L, Montañá X, Llovet JM, Bruix J. Chemoembolization of hepatocellular carcinoma with drug eluting beads: efficacy and doxorubicin pharmacokinetics. J Hepatol 2007;46:474-81.

63. Poon RT, Tso WK, Pang RW, Ng KK, Woo R, Tai KS, Fan ST. A phase I/II trial of chemoembolization for hepatocellular carcinoma using a novel intra-arterial drug-eluting bead. Clin Gastroenterol Hepatol 2007;5:1100-8.

64. Li X, Feng GS, Zheng CS, Zhuo CK, Liu X. Expression of plasma vascular endothelial growth factor in patients with hepatocellular carcinoma and effect of transcatheter arterial chemoembolization therapy on plasma vascular endothelial growth factor level. World J Gastroenterol 2004;10:2878-82.

65. Llovet JM, Ricci S, Mazzaferro V, Hilgard P, Gane E, Blanc JF, de Oliveira AC, Santoro A, Raoul JL, Forner A, Schwartz M, Porta C, Zeuzem S, Bolondi L, Greten TF, Galle PR, Seitz JF, Borbath I, Häussinger D, Giannaris T, Shan M, Moscovici M, Voliotis D, Bruix J; SHARP Investigators Study Group. Sorafenib in advanced hepatocellular carcinoma. N Engl J Med 2008;359:378-90.

66. Cheng AL, Kang YK, Chen Z, Tsao CJ, Qin S, Kim JS, Luo R, Feng J, Ye S, Yang TS, Xu J, Sun Y, Liang H, Liu J, Wang J, Tak WY, Pan H, Burock K, Zou J, Voliotis D, Guan Z. Efficacy and safety of sorafenib in patients in the Asia-Pacific region with advanced hepatocellular carcinoma: a phase III randomised, double-blind, placebo-controlled trial. Lancet Oncol 2009;10:25-34.

67. Park JW, Finn RS, Kim JS, Karwal M, Li RK, Ismail F, Thomas M, Harris R, Baudelet C, Walters I, Raoul JL. Phase II, open-label study of brivanib as first-line therapy in patients with advanced hepatocellular carcinoma. Clin Cancer Res 2011;17:1973-83.

How to cite this article: Buell JF. Hepatoma Research: the beginning of a new forum. Hepatoma Res 2015;1:1-5.

Source of Support: Nil. Conflict of Interest: None declared. 